\title{
STUDI META-ANALISIS HUBUNGAN ANTARA SOCIAL SUPPORT DENGAN PTSD (POST TRAUMATIC STRESS DISORDER)
}

\author{
Siti Urbayatun \\ Universitas Ahmad Dahlan
}

\begin{abstract}
Reason for this meta analysis study is the variance of relation between social support and Post Traumatic Syndrome Disonder (PTSD). Six (6) articles show that social support correlales megatively with PTSD. Especially aff oction, instumental and activity support. Social support role as buffer between stressors and PTSO.
\end{abstract}

Keyword: meta analysis, social support, post traumatic stress disorder(PTSD).

\section{PEN GANT.AR}

Perkembangan riset tentang Post Traumatic Stress Disorder (PTSD) banyak dilatarbelakangi oleh berbagai kejadian yang melanda manusia maupun alam, khususnya berkaitan dengan kejadian-kejadian yang bersifat traumatis. Konsep tentang PTSD menjadi bahan perdebatan oleh para ahli, antara lain berkaitan dengan dasar-dasar konsepnya (Jones dkk., 2003). Perbedaan pandangan itu seperti yang diungkap oleh Trimble (Jones dkk., 2003) yang menyatakan bahwa problem-problem semacam PTSD sudah diketahui beberapa ratus tahun meskipun dengan istilah yang berbeda. Sebaliknya Young (Jones dkk., 2003) membantah dan menyatakan bahwa PTSD merupakan diagnosis yang muncul karena pengaruh budaya dan baru muncul pada akhir abad 20. Jones dkk. (2003) kemudian meneliti bahwa psikopatologi pada trauma bukanlah variabel yang bersifat statis dan bahwa kultur/budaya dapat mempengaruhi ekspresi memori tentang kejadian-kejadian yang distress tersebut. Salah satu simtom utama PTSD yakni flashbacks ditengarai merupakan simtom yang bersifat culture- bound. Salah satu contohnya adalah perkembangan teknologi audiovisual, seperti TV dan video yang berkembang pada abad 20 , diyakini turut mempengaruhi terjadinya flashbacks pada kejadian-kejadian yang telah berlalu. Akibatnya korban seperti melihat film tentang kejadian traumatis yang diputar kembali (Jones dkk., 2003; Keliner \& Dowben, 2007).

Prevalensi terjadinya PTSD menunjukkan hasil yang bervariasi untuk setiap penelitian. Menurut data dalam DSM $N$ (APA, 1994) disebutkan bahwa $3 \%-58 \%$ korban yang mengalami kejadian- kejadian traumatis akan mengalami PTSD dan sebagian mengalami gejala- gejala subklinis PTSD; misalnya di kamp konsentrasi, tahanan perang $50 \%$ mengalami PTSD, sedangkan korban kejahatan, khususnya perkosaan, $80 \%$ juga mengalami PTSD (Tucker of al, 2000). Studi tentang stres traumatis menemukan bahwa gangguan traumatis bukan saja mengancam korban, tetapi juga membawa dampak pada pekerjaan-pekerjaan yang mengandung bahaya atau mengancam kematian, seperti pekerja di palang merah, polisi, pemadam kebakaran, atau pekerja yang menangani 
bencana alam, termasuk terapis. Pekerjaanpekerjaan ini mengandung apa yang disebut sebagai vicarious traumatization (Linley \& Joseph, 2005).

Meskipun kejadian traumatis secara umum berhubungan dengan dampak psikososial negatif, beberapa penelitian temyata melaporkan korban juga mengalami perubahan positif dalam hidupnya, seperti peningkatan hubungan interpersonal dan spiritualitas (Salo, of al., 2005; Linley \& Joseph, 2005).

Peneliti yang memfokuskan pada dampak negatif pengalaman traumatis kemudian mencoba mencari penyebab yang memunculkan gangguan stres pasca trauma, antara lain level of exposure (tingkat terkenanya musibah), peritraumatic stress dan efek fisiologis stres serta tipe socia' support ( Titchenor dkk., 1996; Ehlers dkk. 1998; Tuckerdkk., 2000).

Sludi meta analisis ini akan memfokuskan pada hubungan antara social support dengan PTSD. Berdasarkan berbagai temuan, baik yang bersifat positif atau negatif akan dilakukan analisis sehingga tidak menjadikan para peneliti yang tertarik mengkaji hubungan antara social support dengan PTSD menjadi ragu-ragu karena ada integrasi dari sejumlah penelitian individual sehingga menjadi suatu kesimpulan yang integratif.

Masalah penelitian akan dirumuskan sebagai berikut: bagaimana hubungan antara social support dengan PTSD yang dapat ditarik dari serangkaian hasil studi atau penelitian terkait?

\section{DASARTEORI}

\section{PTSD (Post Traumatic Stres Dusorder)}

Diagnostic and Statistical Manual of

Mental Disorders (DSM) N memberi batasan PTSD dengan sejumlah simptom/ ciri yang dapal muncul ketika individu terkena stresor traumatis. DSM N (1994) mengelompokkan gangguan stress pasca trauma ke dalam kelompok Anxiefy Disorders.

Gejala PTSD baru diteliti secara intens pasca Perang Dunia I, H, Perang Korea, Perang Vletnam dan baru masuk dalam Diagnosis DSM edidi ttl (1980). Taylor dkk. (1998) serta Hart (2006) membandingkan perbedaan simptom yang menjadi faktor faktor dalam PTSD menurut DSM III (1980), DSM III-R ( 1987) dan DSM N (1994) \&. DSM IV-TR (2000) sebagai berikut:

1) Faktor faktor yang menjadi simptom dalam PTSD menurut DSM III (1980) adalah 3 faktor, dikelompokkan dalam faktor $B, C_{1}$ dan $D$ yang keseluruhan sejumtah 12 simtom (faktor A merupakan stressor PTSD itu sendiri yang membatasi adanya prasyarat kejadian yang intens dan dapat menimbulkan trauma). Adapun Faktor B terdiri dari 3 simtom (reexperiencing), faktor C ( 3 simtom numbing of responsiveness, contoh restricted affect) dan faktor D (6 simptom lain, termasuk hyperarousal, avoidance of trauma related-stimuli dan guilt about surviving the trauma) sehingga keseluruhan berjumlah 12 simptom.

2) Ciri-ciri PTSD menurut DSM III-R ( 1987) sudah memasukkan PTSD yang terjadi pada anak-anak dan mendefinisikan stressor pencetus/kriteria A sebagai pengalaman yang di luar jangkauan normal dan menimbulkan stres yang dirasakan oleh hampir semua orang: faktor B bertambah menjadi 5 simtom, faktor $C$ bertambah menjadi 7 simtom, dan faktor $D$ berkurang menjadi 5 simtom, sehingga keseluruhan bejumlah 17 simtom.

3) Ciri-ciri PTSD menurut DSM N (1994) \& DSM N-TR (2000) memperluas definisi stressor/ Kriteria A1 tidak hanya kejadian yang menakutkan atau mengancam kematian atau luka serius atau menyaksikan peristiwa tersebut pada orang tain tetapi juga mempelajari/merasakan pengalaman tersebut pada keluarga dekat atau famili; Kriteria A2 mensyaratkan ketakutan yang intens, menimbulkan ketidakberdayaan atau kengerian. Keseluruhan tetap berjumlah 17 simtom, yakni faktor B 
adalah reexperiencing terhadap kejadian traumatic, faktor $\mathrm{C}$ adalah avoidance of stimuli \& numbing of responsiveness dan faktor $D$ disebut autonomic hyperarousal yang mana 1 simtom dalam faktor $B$ bengeser ke faktor $\mathrm{D}$. Selain itu terdapat kriteria $\mathrm{E}$ yakni simtom harus dialami selama paling tidak 1 bulan dan kriteria $F$ bahwa gangguan tersebut menyebabkan rendahnya dalam fungsi sosial, okupasional, dan fungsi-fungsi penting lainnya.

Para peneliti ada yang mencoba melakukan analisis terhadap faktor-faktor dalam PTSD terse but $d$ atas, misalnya Taylor dkk. (1998) menggunakan analisis fakktor menemukan bahwa simtom PTSD dapat dikelompokkan dalam 2 faktor saja, yakni faktor 1 (intrusions or avoidance) dan faktor 2 (hyperarousal or numbing) dan faktor-faktor ini merupakan satu kesatuan dari faktor yang lebih besar (Taylor dkk. 1998). Para peneliti lain masih menggunakan 3 faktor PTSD dalam studinya yakni re-experience, avoidance \& hyperarousal (Ehlers dkk., 1998; Tucker, dkk., 2000; Self-Brown, 2004; Declercq \& Palmans, 2006; Hart, 2006).

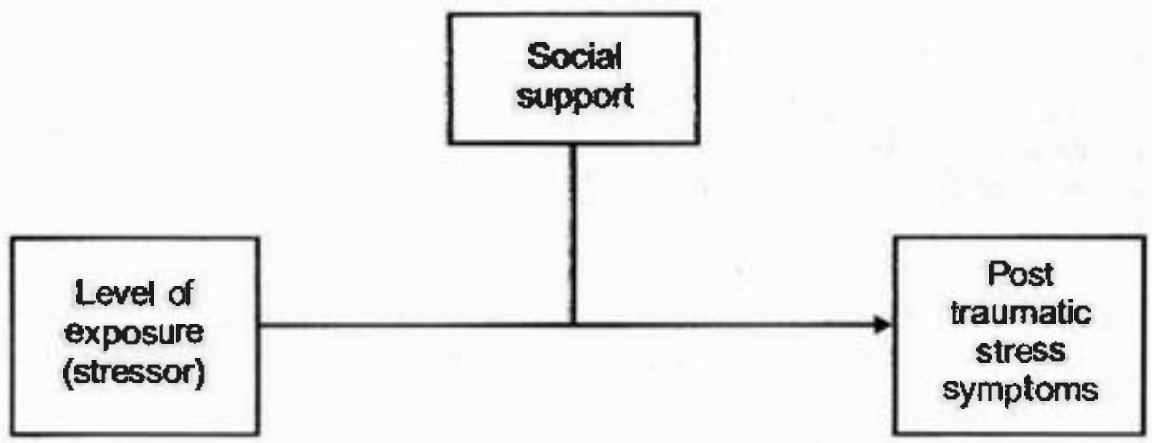

Gambar 1. Social support sebagai moderator antara kejadian traumatls dengan munculnya gejaia stres

Sebagai alternatif, model kedua meyakini bahwa social support mempunyai kemanfaatan tertadap kesehatan fisik dan psikis tidak tergantung pada keberadaan stres. Jadi social support akan menjadi independent variable yang dapat mernpengaruhi dependent variable yakni simtom stress.

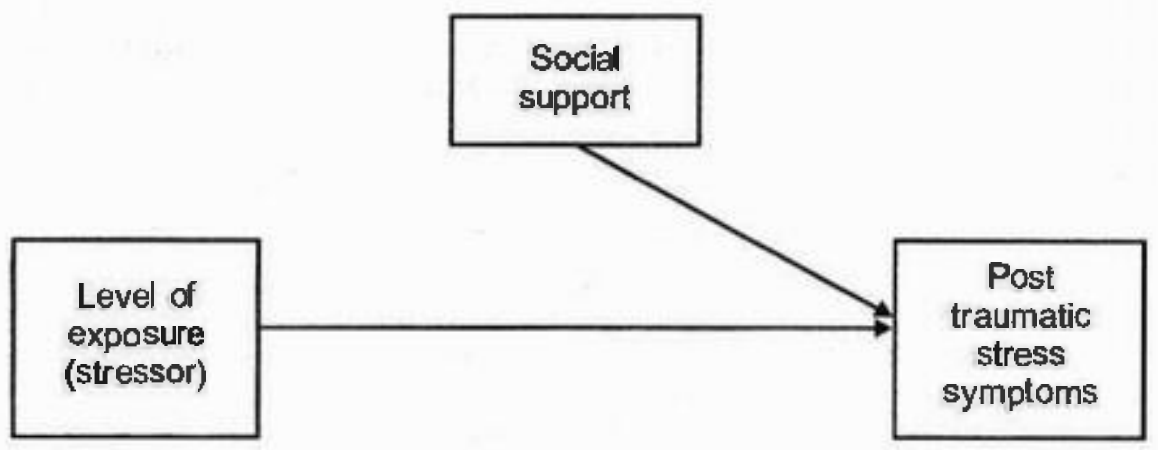

Gambar 2 Social support sebagai variabei yang berdiri sendiri yang akan mempengaruhi munculnya gejala stres 
Kedua model di atas mengasumsikan bahwa stresor dan social supporttidak beihubungan satu sama lain.

Model yang ketiga mengevaluasi model pertama bahwa stresor akan memobilisasi sumber-sumber untuk memberikan support. Adanya hubungan antara stresor kehidupan dengan support menunjukkan adanya mobilisasi jejaring sosial sehingga mencegah individu dari dampak negalif stresor. Konsep yang terakhir ini disebul supressor model atau support mobilization model yang membantah asumsi dalam the buffering stress model bahwa stresor dan support fidak saling berhubungan padahal temuan di lapangan menunjukkan adanya hubungan itu (Kanlasty \& Norris, 1993).

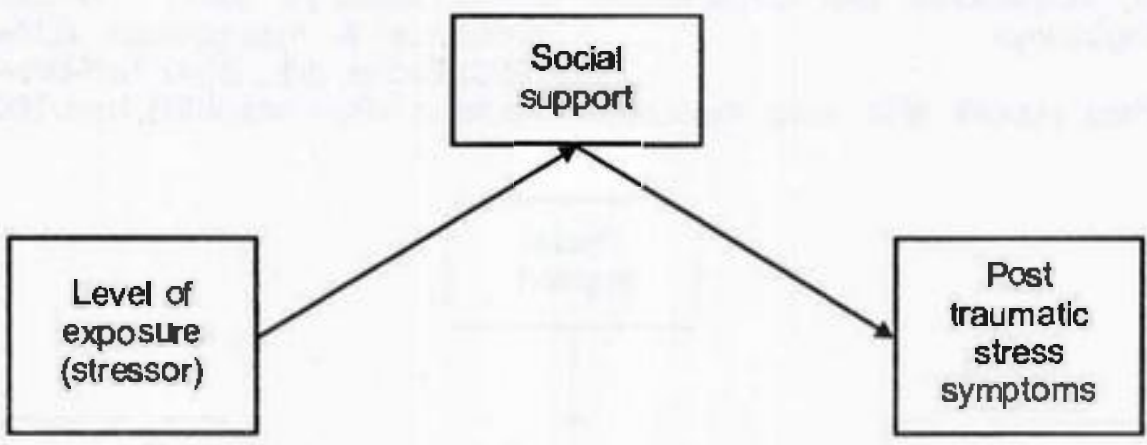

\section{Gambar3. Social support sebagai variabei yang kemunculannya dlpengaruhi oieh munculnya stresor.}

Sebagai langkah untuk mencermati model-model tersebut maka juga akan dilakukan integrasi temuan beberapa studi secara naratif-deskrlptif yang sebagian meneliti tentang efek penyangga maupun efek langsung dari stres. Namun penulis tidak menemukan studi yang menguji suppression model. Hasil-hasil tersebut akan menjadi bahan kajian dalam konklusi hubungan antara stressor dengan social support dan PTSD pada sejumlah penelitian.

Berbagai pengertian atau definisi social support telah dinyatakan oleh para ahli, antara lain Johnson \& Johnson (1991) yang menyatakan bahwa social support sebagai pertukaran sumber-sumber dengan maksud saling mempertinggi kesejahteraan dan keberadaan orang lain yang bisa diandalkan untuk diminta bantuan, dorongan, penerimaan dan perhatian apabila individu mengalami kesulitan. Social Support bukan hanya sekedar memberi bantuan, tetapi yang penting adalah bagaimana persepsi penerima terhadap makna dari bantuan tersebut. Hal yang perlu diperhatikan dalam rangka memberi bantuan adalah persepsi terhadap keberadaan (availability) dan ketepatan (adequacy) dukungan sosial tersebut bagi penerima bantuan, dalam arti bahwa individu yang menerima bantuan sangat merasakan manfaat bagi dirinya.

Social Support dalam penelitian para ahli mempunyai aspek yang bermacammacam, namun beberapa dapat dijadikan suatu kesatuan. Beberapa aspek yang dijadikan sumber meta analisis ini meliputi: (1) Tolal social support, 2) Dukungan afeksi/ affectionate support (berupa dukungan afeksi atau emosi, baik darl proses beragama, proses konseling, famili, teman sebaya, atasan, rekan sekerja), (3) interaksi sosial yang positif/ positive- social interactions (termasuk komunikasi yang positif, penerimaan atau sikap yang positif atau sejauh mana situasi kerja kondusif untuk menceritakan trauma, adanya keluarga yang tanpa kekerasan, misalnya 
dalam penelitian ada variabel family violence (sebagai kondisi interaksi sosial yang berlawanan dengan social support yang akan dijadikan bahan studi). (4) dukungan sarana \& aktivitas (yakni untuk mendukung kinerja seperti transportasi moupun berbentuk aktivitas seperti keeping busy, exercisedan pekerjaan).

\section{Hubungan Antara Socia/ support dengan PTSD}

Terdapat sejumlah studi yang menunjukkan hasil bervariasi antara variabel social support dengan PTSD, sebagian berkorelasi positif dan sebagian berkorelasi negatif, angka korelasinyapun ada yang tinggi dan ada yang rendah; tetapi ada pula yang tidak mencantumkan angka korelasi sehingga tidakdisertakan dalam perhitungan meta analisis, misalnya penelitian Declercq \& Palmans (2006) serta Acierno (2006) namun mengInformasikan adanya hubungan negatif antara kedua variabel. Stephens \& Long (1999) menyebutkan sejumlah penelitian yang menemukan aspek dalam social support, yakni perceived emotional support, sebagai aspek yang paling konsisten memprediksi perubahan positif dalam menghadapi krisis. Ditemukan juga bahwa social support menjadi variabel moderator antara pengalaman traumatik dengan PTSD. Aspek social support yang terbukti berhubungan dengan PTSD adalah: expressing emotion at work (yang dalam studi ini dikelompokkan dalam positive social interactions) serta emotional support from peers (yang dikeiompokkan dalam studi ini sebagai affectionate support). Stephens \& Long (2000) melaporkan bahwa komunikași yang positif dengan rekan sekerja, supervisor maupun teman akan menjadi buffer terhadap kondisi stres traumatik (semua studinya akan dikelompokkan dalam aspek positive social interactions). Tucker ef.al. (2004) meneliti beberapa aspek dari social support yang dapat menurunkan PTSD yakni bantuan berupa konseling serta dari lingkungan pekerjaan, terutama bantuan konseling merupakan prediktor yang cukup signifikan $(46 \%)$ terhadap PTSD. Penelitian Self-Brown (2004) dalam disertasinya ( $w w w$. google.com) melaporkan bahwa kondidi keluarga yang penuh kekerasan (family violence) akan menjadi moderator munculnya PTSD pada remaja (aspek family violence ini dimasukkan sebagai lawan dari positive social interactions sehingga dalam perhitungan arah korelasi akan dibalik). Hart (2006) dalam disertasinya (www. google.com) menemukan bahwa social supporttidak terbukti menjadi buffer terhadap post traumatic stress symploms tetapi aspek affectionate support serta positive social interactions terbukti dapat mengurangi gejala-gejala stress pasca trauma. Acierno (2006) melakukan penelitian pada korban badai Florida yang berusia lanjut dan yang lebih muda; seperti sudah dlsebutkan sebelumnya bahwa meskipun tidak mencantumkan angka korekas| namun menemukan adanya faktor yang dapat mempediksi psikopatologi (termasuk PTSD) pada kedua kelompoktersebutyakni variabel social support dan traumatic exposure. Penelitian Sarmawi di daerah bencana gempa di Bantul, DIY menemukan besarnya koefisien korelasi antara variabel dukungan sosial dengan post-traumatic stress disorder adalah sebesar $=-0,343$ dengan $p=0,043$ $(p<0,05)$.

\section{Hipotesis}

Hipotesis yang diajukan adalah ada hubungan antara social support dengan PTSD.

\section{METODE PENELITIAN}

\section{Prosedur}

Penelltian ini menggunakan metode meta-analisis dengan tahap-tahap sebagai berikut:

†. Formulasi Permasalahan

2. Mengumpulkan data dari studi primer

Pengumpulan data dilakukan melalui penelusuran jurnal elektronik yang diakses dari EBSCO dan Proquest yang dilanggan Universitas Gadjah Mada maupun memanfaatkan jaringan online melalui www google.com dengan kata kunci social support and traumatic stress. 
Teknik pencarian selain melalui aplikasi program komputer, dilakukan pula pencarian secara manual jurnal ilmiah dengan memanfaatkan perpustakaan Fakultas Psikologi UGM. Pencarian online melalui EBSCO khususnya dari Journal of Traumatic Stress Londion menyebutkan rentang tahun publikasi dari tahun 1995 sampai dengan tahun 2007, namun yang tersedia full text mulai tahun 1997 saja; sedangkan dari Proquest dalam Journal of Traumatic Stress London menyebutkan rentang tahun publikasi yang lebih luas dari tahun 1986 sampai dengan tahun 2007, namun yang tersedia full text mulai 1997 sampai dengan tahun 2004 saja. Dari akses EBSCO \& Proquest akhimya hanya berhasil mendapatkan (download) 18 judul penelitian tetapi hanya 4 judul penelitian yang bisa dilakukan meta analisis. Pencarian secara manual jumal ilmiah dengan memantaatkan perpustakaan Fakultas Psikologi UGM mendapatkan14 judul jurnal yang diterbitkan oleh APA yakni Journal of Abnorma! Psychology, Journal of Consulting \& Clinical Psychology. Journal of Personality and Social Psychology. Penulis tidak berasil mendapatkan satupun judul skripsi, tesis maupun disertasi dari akses pelacakan komputer Fakuitas Psikologi UGM dengan kata kunci social support dan PTSD, tetapi behasil mendapatkan satu (1) judul skripsi yang belum dipublikasikan di Fakultas Psikologi Universitas Ahmad Dahlan. Selain iu hasil penelusuran dari www.google.com berhasil mendapatkan dua (2) buah disertasi yang yang bisa didownload secara bebas (treecharge) dan dapat dijadikan bahan meta analisis.

3. Pengkodean data dalam tiap studi

Setelah dilakukan permilahan dari berbagai penelitian yang terkait antara socia! support dan PTSD maka informasi-informasi penting dicatat, meliputi: (a) tahun publikasi, (b) peneliti, (c) karakteristik subyek penelitian, seperti jenis kelamin, usia, latar sosial/pekerjaan, (4) hasil korelasi, (5) hasil taraf signifikansi, (8) reliabilitas alat ukur (baik untuk variabel $X J$ social supportmaupun variabel Y( PTSD).

\section{TeknikAnalisis Data}

Banyak teknik yang dapat digunakan untuk mengintegrasikan hasilhasil penelitian. Teknik-teknik tersebut mempunyai rentangan dari yang paling sederhana sampai yang bersifat kompleks. Teknk sederhana adalah pemaduan naratif, sedangkan teknik yang lebih kompleks adalah dengan pemanfaatan psikometrik. Dalam melakukan meta analisis ini penulis mencoba mengintegrasikan penemuanpenemuan secara naratif sekaligus penghitungan psikometrik, terutama mengacu pada pendapat Hunter \& Schmidt (1990). Menurut Hunter dan Schmidt (1990) koreksi artifak sebagai titik pandang melakukan analisis dari studi korelasi membutuhkan informasi tentang nilai $r$, adapun jika dalam membaca nilai korelasi ternyata tidak mendapatkan harga $r_{1}$ dan yang tersedia nilal $t$, $F$ dan d maka nilai itu ditransformasikan menjadi r melalui model persamaan r. Penelitian ini hanya menemukan nilai yang tidak bisa dibaca atas dasar nilai $r$ (Declerq \& Palmans, 2006; Acierno dkk, 2006) akan tetapi juga tidak tersedia nilai $t, F$ den $d$ sehingga kedua penelitian di atas tidak dapat digunakan untuk perhitungan meta analisis.

Langkah-langkah yang ditempuh dalam analisis untuk koreksi artifak penelitian korelasi adalah sebagai berikut (HunterdanSchmidt, 1990):

a. Transformasi harga $F$ ke dalam $t, d$, danr.

b. Bare-Bone meta analysis: koreksi kesalahan sampling

1) Menghitung rata-rata (mean) korelasi populasi

2) Menghitung varians $r_{{ }_{x y}}$

3) Menghitung varians kesalahanpengambilan sampel

4) Dampak pengambilan sampel 
c. Koreksi Kesalahan Pengukuran

1) Menghitung mean gabungan

2) Menghitung korelasi populasi yang dikoreksi oleh kesalahan pengukuran

3) Interval kepercayaan

4) Dampak variasi reliabilitas

\section{Karakteristik Sampei}

Karakteristik sampel yang dijadikan sumber meta analsisis adalah seperti terlihat dalam tabel 1.

Tabel 1.

Karakteristik Sampel Penelitian

\begin{tabular}{|c|c|c|c|c|c|c|c|c|c|}
\hline \multirow[b]{2}{*}{ No. } & \multirow[b]{2}{*}{ Tahun } & \multirow[b]{2}{*}{ Peneliti } & \multicolumn{3}{|c|}{ Sampel } & \multirow[b]{2}{*}{$\mathrm{Jml}$} & \multirow{2}{*}{$\begin{array}{c}\text { Karakteristik } \\
\text { subyek }\end{array}$} & \multicolumn{2}{|c|}{ Usia } \\
\hline & & & Lk & $\mathrm{Pr}$ & $\begin{array}{c}\text { Tanpa } \\
\text { ket }\end{array}$ & & & $\underset{\text { (th) }}{M}$ & SD \\
\hline 1 & 1999 & $\begin{array}{l}\text { Stephens \& } \\
\text { Long }\end{array}$ & 460 & 57 & - & 517 & Polisi & $\begin{array}{l}21-62 \\
(41.5)\end{array}$ & - \\
\hline 2 & 2000 & $\begin{array}{l}\text { Stephens \& } \\
\text { Long }\end{array}$ & 433 & 53 & - & 486 & Polisi & $\begin{array}{l}21-62 \\
(41.5)\end{array}$ & - \\
\hline 3 & 2000 & Tuckerdkk. & 60 & 25 & - & 85 & $\begin{array}{l}\text { Masyarakat } \\
\text { korban bom } \\
\text { Oklahoma }\end{array}$ & 42 & 12.4 \\
\hline \multirow[t]{3}{*}{4} & 2004 & Seff-Brown & 60 & 61 & - & 121 & $\begin{array}{l}\text { Palajar dan } \\
\text { salah saut } \\
\text { orang tua atau } \\
\text { wali }\end{array}$ & 15 & - \\
\hline & 2006 & Aciemo 7 & 401 & 727 & 2 & 1130 & $\begin{array}{l}\text { Lansia korban } \\
\text { bachi Aorida }\end{array}$ & 77 & 7.9 \\
\hline & 2006 & Acierno*) & 151 & 257 & 5 & 413 & $\begin{array}{l}\text { adult korben } \\
\text { badaj Florida }\end{array}$ & 429 & 10.5 \\
\hline \multirow[t]{2}{*}{5} & 2006 & Hart & 100 & 0 & - & 100 & $\begin{array}{l}\text { Voteran } \\
\text { tenlara PO } \mid \mathrm{z} \\
\text { Perang Korea }\end{array}$ & 77.19 & 4.77 \\
\hline & 2006 & $\begin{array}{l}\text { Declercq \& } \\
\text { Palmans })\end{array}$ & 458 & 86 & - & 544 & $\begin{array}{c}\text { Pokerifit of } \\
\text { Palang Marah } \\
\text { Belgia }\end{array}$ & 40.8 & 10.65 \\
\hline \multirow[t]{2}{*}{6} & 2007 & Sarmawi & 25 & 53 & - & 78 & Siswa SMU & $\begin{array}{l}16-18 \\
(17)\end{array}$ & - \\
\hline & & TOTAL & 1138 & 249 & & 1387 & & & \\
\hline
\end{tabular}

Ket. \% tidak ditemukan angka korelasi sehingga tidak dikutsertakan dalam perhitungan.

Jumlah subyek pada seluruh studi (6artikel)yang dijadikan bahan metaanalisis berjumlah 1387, terdiri dari Laki-laki sebanyak 1138 ( $82 \%$ ) dan perempuan sebanyak249 (18\%). Jumlah sampel terkecil sebanyak 78 subyek dan terbesar sebanyak 517 subyek. Rata-rata sampel untuk setiap studisebanyak231 subyek 
Tabel 2

Rangkuman Sejumlah Studi tentang Hubungan antara Social Support dengan PTSD

\begin{tabular}{|c|c|c|c|c|c|c|c|c|c|}
\hline \multirow[b]{2}{*}{ No. } & \multirow[b]{2}{*}{ Tahun } & \multirow[b]{2}{*}{ Peneliti } & \multicolumn{3}{|c|}{ Sampel } & \multirow[b]{2}{*}{$\mathrm{Jml}$} & \multirow{2}{*}{$\begin{array}{c}\text { Karakteristik } \\
\text { subyek }\end{array}$} & \multicolumn{2}{|c|}{ Usia } \\
\hline & & & L.k & Pr & $\begin{array}{c}\text { Tanpa } \\
\text { ket. }\end{array}$ & & & $\begin{array}{c}M \\
\text { (th) }\end{array}$ & SD \\
\hline 1 & 1999 & $\begin{array}{l}\text { Stephens \& } \\
\text { Long }\end{array}$ & 460 & 57 & - & 517 & Polisi & $\begin{array}{l}21-62 \\
(41.5)\end{array}$ & - \\
\hline 2 & 2000 & $\begin{array}{l}\text { Stephens \& } \\
\text { Long }\end{array}$ & 433 & 53 & - & 486 & Polisi & $\begin{array}{l}21-62 \\
(41.5)\end{array}$ & - \\
\hline 3 & 2000 & Tucker dkk & 60 & 25 & - & 85 & $\begin{array}{l}\text { Masyarakat } \\
\text { kortanbom } \\
\text { Oflatioma }\end{array}$ & 42 & 124 \\
\hline \multirow[t]{3}{*}{4} & 2004 & Self-Brown & 60 & 61 & - & 121 & $\begin{array}{l}\text { Pelajir dan } \\
\text { salahsatu } \\
\text { orang tua atau } \\
\text { wali }\end{array}$ & 15 & - \\
\hline & 2006 & Acierno y & 401 & 727 & 2 & 1130 & $\begin{array}{c}\text { Lansia korban } \\
\text { badai Florida }\end{array}$ & 71 & 79 \\
\hline & 2006 & Aciemo') & 151 & 257 & 5 & 413 & $\begin{array}{l}\text { adult korban } \\
\text { badel Florida }\end{array}$ & 42.9 & 10.5 \\
\hline \multirow[t]{2}{*}{5} & 2006 & Hart & 100 & 0 & - & 100 & $\begin{array}{l}\text { Veteran } \\
\text { tentare PD I \& } \\
\text { Perang Korea }\end{array}$ & 77.19 & 4.77 \\
\hline & 2006 & $\begin{array}{l}\text { Declercq \& } \\
\text { Palmans') }\end{array}$ & 458 & 86 & - & 544 & $\begin{array}{c}\text { Peleyje of } \\
\text { Palang Merah } \\
\text { Belgia }\end{array}$ & 408 & 10,65 \\
\hline \multirow[t]{2}{*}{6} & 2007 & Sarmawi & 25 & 53 & - & 78 & Siswa SMU & $\begin{array}{c}16-18 \\
(17)\end{array}$ & - \\
\hline & & TOTAL & 1138 & 249 & & $\{387$ & & & \\
\hline
\end{tabular}

Ket. ") tidak ditemukan angka korelasi sehingga tidak diikutsertakan dalam perhitungan.

Jumlah subyek pada seluruh studi (6 artikel)yang dijadikan bahan metaanalisis berjumlah 1387, terdiri dari Laki-laki sebanyak 1138 (82\%) dan perempuan sebanyak 249 (18\%). Jumlah sampel terkecil sebanyak 78 subyek dan terbesar sebanyak 517 subyek. Rata-rata sampel untuk setiap stud i sebanyak 231 subyek 
Tabol3.

\section{Rangkuman Sejumlah Studj tontang Hubungan antara Social Support dengan PTSD}

\begin{tabular}{|c|c|c|c|c|c|c|c|c|c|c|c|c|}
\hline $\begin{array}{r}\text { Nen. } \\
. \cdot \\
\end{array}$ & 3 & thes: & $\begin{array}{l}\text { Sub } \\
\text { yok }\end{array}$ & $\begin{array}{l}\text { karak } \\
\text { terist } \\
\text { ik }\end{array}$ & 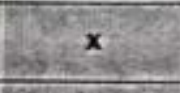 & $Y$ & 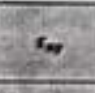 & ?: & Befia & Siletes & $\mathrm{K}_{\mathrm{m}}$ & 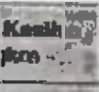 \\
\hline 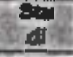 & sis Pand & Tahuin & $\mathbf{N}$ & & $98(4,8)$ & & & & a & $x_{15}$ & $\geqslant T_{m}$ & $b=\ln$ \\
\hline 19 & (2) & (3) & (4) & (5) & ento(6) & (7) & (8) & $P$ & $(10)$ & (10) & $(12)$ & $(25)$ \\
\hline 91, & $\begin{array}{l}\text { Shephet: } \\
\text { L Lang }\end{array}$ & tast & 57 & Potsi & 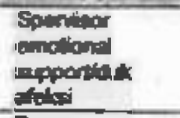 & PTED & 470 & 0001 & 0.4 & 0.90 & 0916 & 0.959 \\
\hline b) & $\begin{array}{l}\text { Slephent } \\
\text { E Lnetg }\end{array}$ & 4909 & 577 & Poti= & $\begin{array}{l}\text { Poer- } \\
\text { motiond } \\
\text { mppity duk }\end{array}$ & PTSO & -120 & $\Rightarrow f 00$ & DAS & 0.90 & 0.918 & 0.949 \\
\hline G) & $\begin{array}{l}\text { suphan } \\
\text { along }\end{array}$ & 1959 & $\$ 17$ & Poild: & 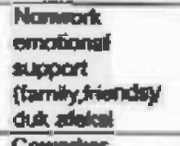 & PTSD & 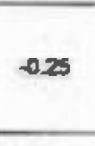 & 4.001 & OB4 & 050 & 0.876 & 0949 \\
\hline d) & $\begin{array}{l}\text { Saphent } \\
\text { E Lond }\end{array}$ & 799 & sa7 & Polde: & 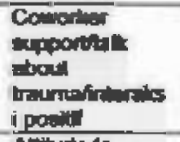 & PTSD & -437 & 400 & b.Bt & 090 & os & 0.98 \\
\hline 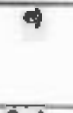 & $\begin{array}{l}\text { Suphom } \\
\text { L Long }\end{array}$ & 1989 & $5 \pi$ & Pot: & 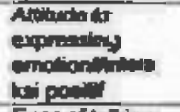 & PTSP & +21 & 40.097 & 0.5 & 090 & orat & 0.949 \\
\hline 2I & $\begin{array}{l}\text { Sionthas } \\
\text { a Long }\end{array}$ & 2000 & 40 & $\mathrm{~Pa}^{-1}$ & 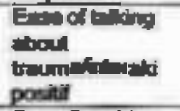 & PTSD & 030 & 001 & 081 & 0.90 & as & 0,949 \\
\hline 4 & $\begin{array}{l}\text { Sophan } \\
\text { L Lang }\end{array}$ & 2000 & 400 & Rt: & 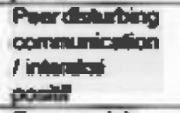 & PTED & tos & $=005$ & Oat & 090 & 0.9 & 0.949 \\
\hline d & $\begin{array}{l}\text { Sthophes } \\
\text { t Long }\end{array}$ & 2000 & 406 & Pollor & 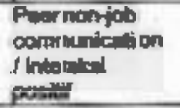 & PTSD & -0.17 & $\infty 01$ & DBO & 090 & 0.894 & 0.949 \\
\hline d) & $\begin{array}{l}\text { Stopher } \\
\text { Alone }\end{array}$ & 2000 & 40.4 & 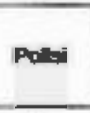 & 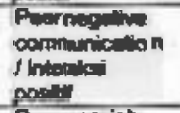 & PTSD & $-0.7 \mathrm{~m}$ & $=0 \mathrm{PS}$ & 0.79 & 000 & 0.54 & 0,909 \\
\hline$\Rightarrow$ & $\begin{array}{l}\text { Shahen } \\
\text { atorat }\end{array}$ & 2000 & 406 & Fot: & 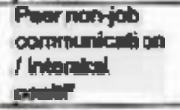 & PISD & -025 & 0.01 & AT & $0=0$ & 0.048 & 0.949 \\
\hline 7) & SLan & 2000 & $4 a s$ & Putai & 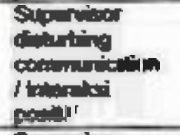 & PTSD & 0.14 & 801 & a.n & 0.90 & 0.040 & 0.949 \\
\hline c) & SLand & 2000 & 40 & Polis & 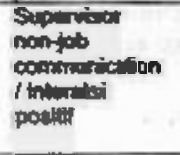 & PTSP & -0.7 & 0.01 & Ders & 000 & 0.050 & 0,949 \\
\hline 4 & $\begin{array}{l}\text { Stophens } \\
\text { aLong }\end{array}$ & 2000 & 405 & Polsis & 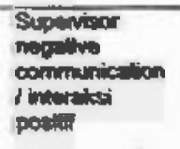 & PTSD & oor & 3005 & 084 & 0.50 & 0.018 & 0,96 \\
\hline 4 & Staphis & 2000 & 40 & Porsi & 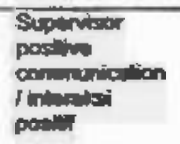 & PTsD & 018 & 001 & 0.8 & 0.90 & 0.027 & 0,94 \\
\hline
\end{tabular}




\begin{tabular}{|c|c|c|c|c|c|c|c|c|c|c|c|c|}
\hline 3.a) & $\begin{array}{l}\text { Tucker } \\
\text { dkk. }\end{array}$ & 2000 & 85 & $\begin{array}{c}\text { Dewa } \\
\Rightarrow\end{array}$ & $\begin{array}{l}\text { Talkifg with } \\
\text { others helpod } \\
\text { interaksi positu }\end{array}$ & PTSD & -0.15 & 0.175 & - & 0.90 & - & 0.949 \\
\hline b) & $\begin{array}{l}\text { Tucker } \\
\text { dkk }\end{array}$ & 2000 & 85 & $\begin{array}{c}\text { Dewa } \\
\text { sa }\end{array}$ & $\begin{array}{l}\text { Religion } \\
\text { nelpetl' dik } \\
\text { efoks }\end{array}$ & PTSD & -0.77 & 0.131 & - & 0.90 & - & 0.949 \\
\hline d & $\begin{array}{l}\text { Tucker } \\
\text { dikk. }\end{array}$ & 2000 & 85 & Dewa & 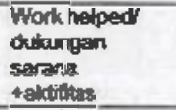 & PTSD & -0.29 & 0.008 & - & 0.90 & - & 0.949 \\
\hline 4 & $\begin{array}{l}\text { Tucker } \\
\text { dłkk. }\end{array}$ & 2000 & 85 & Dowa & 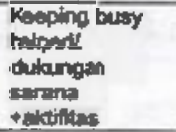 & PTSD & 0.12 & 0.290 & - & 0.90 & - & 0,949 \\
\hline 하 & $\begin{array}{l}\text { Tucker } \\
\text { dkk. }\end{array}$ & 2000 & 85 & $\begin{array}{c}\text { Dewa } \\
\text { so }\end{array}$ & $\begin{array}{l}\text { Counating } \\
\text { helpedy dut: } \\
\text { oftensi }\end{array}$ & PTSD & $\begin{array}{c}-058 \\
7\end{array}$ & 0.0001 & - & 0.90 & - & 0,949 \\
\hline ) & $\begin{array}{l}\text { Tucker } \\
\text { dkke. }\end{array}$ & 2000 & 85 & $\operatorname{Dowa}_{80}$ & 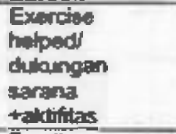 & PTSD & 0.21 & 0.068 & - & 0.90 & - & $0 ; 949$. \\
\hline 4. & $\begin{array}{l}\text { Solf } \\
\text { Enown }\end{array}$ & 2004 & $12 t$ & $\begin{array}{l}\text { Rerra } \\
\text { fa } 8 \\
\text { crang } \\
\text { tuat } \\
\text { ofi }\end{array}$ & $\begin{array}{l}\text { Famiy } \\
\text { violancel } \\
\text { intaratesipocitit }\end{array}$ & PTSD & -0.497 & $<001$ & - & - & - & - \\
\hline 5.a) & Acismo & 2005 & ${ }_{0}^{193}$ & latis & $\begin{array}{l}\text { Tolsodial } \\
\text { support }\end{array}$ & PISD & -7 & 40.05 & - & - & - & - \\
\hline bi) & Aciempo & 2006 & 413 & $\begin{array}{l}\text { dowa } \\
\Rightarrow a\end{array}$ & $\begin{array}{l}\text { Iotai singial } \\
\text { support }\end{array}$ & Pाक्षण & $y$ & -0.05 & - & - & - & - \\
\hline 6a) & Hart & 2006 & wo & $\begin{array}{l}\text { Pensai } \\
\text { unan }\end{array}$ & $\begin{array}{l}\text { Indidientid } \\
\text { support }\end{array}$ & PISD & -0.15 & 0.14 & 0193 & 0.97 & 0.964 & 0.985 \\
\hline b) & Hart & 2006 & 500 & $\begin{array}{l}\text { Pensi } \\
\text { unan }\end{array}$ & $\begin{array}{l}\text { Emotional } \\
\text { sapport dut } \\
\text { afeksi }\end{array}$ & PTSO & $-0 ; 16$ & 0.11 & 0.84 & 0.97 & 0.916 & 0985 \\
\hline द & Hart & 2006 & 100 & $\begin{array}{l}\text { Pensi } \\
\text { warn }\end{array}$ & 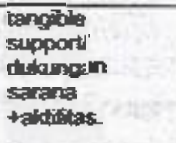 & FISD & -0.02 & 0.88 & 0.89 & 097 & 0.943 & 0.985 \\
\hline d) & Hart & 2006 & 100 & $\begin{array}{l}\text { Perasi } \\
\text { urran }\end{array}$ & 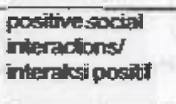 & PTSD & -038 & 0001 & 0.90 & 0.97 & 0.949 & 0.985 \\
\hline 7. & $\begin{array}{l}\text { Dederca } \\
\text { g } \\
\text { Patmans }\end{array}$ & 2006 & 544 & $\begin{array}{c}\text { Dewa } \\
\text { so }\end{array}$ & $\begin{array}{l}\text { Percainin } \\
\text { social sapport }\end{array}$ & PTSD & $\Rightarrow$ & - & 0.923 & $\begin{array}{c}0.93 \\
1\end{array}$ & 0.961 & 0.965 \\
\hline 8 & Sarmover & 2007 & 78 & Remo & 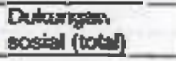 & PTSD & -0.343 & 0.043 & a.956 & $\begin{array}{c}0.55 \\
7\end{array}$ & 0.917 & 0.958 \\
\hline
\end{tabular}

Ket:

*) ditambah tanda minus karena dalam konteks/ penjełasan korelasi negatif

-) Idk ada angka korelasi tapi dijelaskan bahwa arah korelasi negatif, 3 studi ini tidak dikutkan dalam mete analisis 
Mengingat aspek-aspek dalam social support di atas masih bervariasi maka akan dimasukkan dalam nama-nama baru yang sesuai dengan pengertian social support dalam penelitian ini, yakni: 1) total social support; 2) dukungan afeksi, 3) dukungan interaksi sosial yang positif, 4) dukungan sarana \& aktifitas.

Tabel 4.

Lembar kerja Meta analisis (untuk variabel total social support)

\begin{tabular}{|c|c|c|c|c|c|c|c|c|c|}
\hline Studi & Peneliti & Tahun & $\mathrm{N}$ & karakteristik & $x_{x y}$ & $\mathrm{ros}$ & $r_{y y}$ & $a=r_{x}$ & $b=r_{x y}$ \\
\hline (1) & (2) & $(3)$ & (4) & $(5)$ & (6) & $(7)$ & (8) & (9) & $(10)$ \\
\hline 1 & SelfBroum & 2004 & 121 & $\begin{array}{l}\text { Remria \& } \\
\text { orang } \\
\text { Marwati }\end{array}$ & -0.49 & - & - & - & - \\
\hline 2 & Hert & 2006 & 100 & Pensiurian & -0.15 & 0.93 & 097 & 0.964 & 0.985 \\
\hline \multirow[t]{2}{*}{3} & Samawi & $200 \%$ & 78 & Rentiag & -0.343 & 0.916 & 0.957 & 0.917 & 0.958 \\
\hline & JMLAH & & 299 & & -0.983 & 1.846 & 1.927 & 1.881 & 1.943 \\
\hline
\end{tabular}

Tabel5.

Lembar kerja Meta analisis (untuk aspek dukungan afeksi)

\begin{tabular}{|c|c|c|c|c|c|c|c|c|c|}
\hline Studi & Penelifi & Tahun & $\mathrm{N}$ & karakteristik & $r_{x y}$ & Sor & $r_{n}$ & $a=r_{x z}$ & $b=f_{x y}$ \\
\hline (1) & (2) & (3) & (4) & $(5)$ & (6) & (n) & $(8)$ & (9) & $(10)$ \\
\hline \multicolumn{9}{|l|}{1} & 0.949 \\
\hline 2 & Stephens \& Long & 1999 & & Polisi & -0.28 & 0.84 & 0.90 & 0.916 & 0.949 \\
\hline 3 & Stephens \& Long & 1999 & & Pofisi & -0.25 & a.84 & 0.90 & 0.916 & 0.949 \\
\hline \multirow[t]{2}{*}{4} & Hart & 2006 & 100 & Pensiman & -0.16 & 0.84 & 0.97 & 0.916 & 0.985 \\
\hline & NMLAH & & 617 & & & & & & \\
\hline
\end{tabular}


Tabel 6.

Lembar kerja Meta analisis (untuk aspek interaksi sosial positif)

\begin{tabular}{|c|c|c|c|c|c|c|c|c|c|}
\hline Studi & Peneliti & Bhum & $N$ & karakteristik & $r_{x y}$ & $\mathbf{r}_{\mathbf{m a}}$ & $i_{n}$ & $a=r \cdot a$ & $\mathrm{~b}={ }_{2} \mathrm{I}_{x y}$ \\
\hline (1) & $5057=0 .(2)$ & (3) & (4) & (5) & (6) & (7) & (8) & (9) & (10) \\
\hline 1 & Stephens \& Long & 1999 & 517 & Polisi & -0.37 & 0.81 & 090 & 0.9 & 0.949 \\
\hline 2 & Stephens \& Long & 1999 & & Polisí & -0.21 & 0.52 & 0.90 & 0.721 & 0.949 \\
\hline 3 & Stephens \& Long & 2000 & 486 & Polfis & -0.38 & 0.81 & 0.90 & 0.9 & 0,949 \\
\hline 4 & Stephens \& Long & 2000 & & Poisi & -0.06 & 0.81 & 0.90 & 09 & 0,949 \\
\hline 5 & Stephens \& Long & 2000 & & Pollisi & -0.17 & 0.90 & 0.90 & 0.894 & 0,949 \\
\hline 6 & Stephens \& Long & 2000 & & Polisi & -0.17 & 0.73 & 0.90 & 0.854 & 0.949 \\
\hline 7 & Stephens \& Long & 2000 & & Pollsi & -0.25 & 0.78 & 0.90 & 0.883 & 0,949 \\
\hline 8 & Stephens \& Long & 2000 & & Polisi & -0.14 & 0.89 & 0.90 & 0.943 & 0,949 \\
\hline 9 & Stephens \& Long & 2000 & & Polisi & -0.21 & 0.88 & 0.90 & 0,938 & 0,949 \\
\hline 10 & Stephens \& Long & 2000 & & Polisi & -0.07 & 0.84 & 0.90 & 0.916 & 0,949 \\
\hline 11 & Stephens \& Long & 2000 & a & Polist & -0.18 & 0.86 & 090 & 0.927 & 0,949 \\
\hline 12 & Tucker dkk. & 2000 & 85 & Dewisa & -0.15 & - & 0.90 & - & 0,949 \\
\hline 13 & Self-Brown & 2004 & $12 t$ & $\begin{array}{l}\text { Remalea } \\
\text { orang } \\
\text { tuarwali }\end{array}$ & -0.49 & - & - & - & $\cdot$ \\
\hline 14 & Hart & 2006 & 100 & Pensiunan & -0.38 & 0.90 & 0.97 & 0.949 & 0.965 \\
\hline
\end{tabular}

Tabel 7 .

Lembar kerja Meta anallsis (untuk aspek dukungan sarana \& aktifitas)

\begin{tabular}{|ccccccccccc}
\hline Studi & & Peneliti & Tahun & $\mathrm{N}$ & karakteristik & $r_{x y}$ & $r_{x x}$ & $r_{y y}$ & $a=r_{y x}$ & $b=r_{y y}$ \\
\hline$(1)$ & & $(2)$ & $(3)$ & $(4)$ & $(5)$ & $(6)$ & $(7)$ & $(8)$ & $(9)$ & $(10)$ \\
\hline 1 & Tucker dkk. & 2000 & 85 & Dewasa & -0.29 & - & 0.90 & - & 0,949 \\
\hline 2 & Tucker dkk. & 2000 & & Dewasa & 0.12 & - & 0.90 & - & 0.949 \\
\hline 3 & Tucker dkk. & 2000 & & Dewasa & 0.21 & - & 0.90 & - & 0,949 \\
\hline 4 & Hart & 2006 & 100 & Pensiunan & -0.02 & 0.89 & 0.97 & 0.943 & 0.985 \\
\hline
\end{tabular}


Hasil meta-analisis tentang hubungan variabel-variabel total social support terhadap PTSD adalah sebagai berikut : (1) Estimasi Mean korelasi populasi, $x y(r)=-0,338$; (2) varians korelasi populasi $=0,135$; (3) varians error, ${ }^{2} e=$ 0,$008 ;(4)$ varians terkoreksi, $(x y)=0,127 ;(5)$ mean gabungan faktor penyusut artifaks, $(A)$ $=3.655$, estimasi mean korelasi populasi setelah dikorekasi measurement error $0=$ Ave $(A)=$ Ave $(r):=-0,0925 ;(7)$ jumlan kuadrat koefisien varians $(M)=0,00163$; (8) varians yang disebabkan oleh variasi artifak, $S^{2}={ }^{2} A^{2}=0,00019 ;(9)$ varians korelasi yang sebenarnya $\operatorname{Var} 0=0,009,(10) \mathrm{SD} 0=$ $0,097(11)$ batas korelasi populasi yang sud ah dikoreksi karena kesalahan pengukuran pada interval kepercayaan $95 \%$ adalah: $0,284 \quad 0,099$. Analisis dampak kesalahan pengambilan sampel variasi reliabilitas dan faktor lainnya yang tidak teridentifikasi adalah sebagai berikut (a) varians yang disebabikan oleh variasi reliabilitas $=0,138$ $\%$, dan (c) faktor lainnya adalah $(93,9 \%$ ). Persentase varians yang disebabkan oleh sampling error adalah $6241 \%$ dark arena factor lain yang belum terspesifikasi adalah $94.126 \%$ Jadi kesalahan yang disebabkan karena kesalahan sampling pada aspek total social support relative besar dan karena kesalahan pengukuran relative kecil.

Hasil meta-analisis tentang hubungan variabel-variabel dukungan afeksi terhadap PTSD adalah sebagai berikut : (1) Estimasi Mean Korelasi populasi, $x y(r)=-0,269$; (2) varians korelasi, $S^{2}\left({ }^{2}\right)=0,075 ;(3)$ varians error, ${ }^{2} e=0,003 ;(4)$ varians terkoreksi, $(x y)=0,072$; $(5)$ mean gabungan faktor penyusut artifaks, $(A)=$ 14.040 (6) estimasi mean korelasi populasi setelah dikorekasi measurement error $(0=$ Ave $(A)=$ Ave $(r):=-0,0192 ;(T)$ jumlah kuadra! koefisien varians (V) $=0,00035$; (8) varians yang disebabkan oleh variasi artifak, $S^{2}={ }^{2} A^{2}=0,00003$; (9) varians korelasi yang sebenarnya Var $0=0,000036$,(10) SD $0=$ 0,019 (11) batas korelasi populasi yang sudah dikoreksi karena kesalahan pengukuran pada interval kepercayaan $95 \%$ adalah: $0,056 \quad 0,018$. Analisis dampak kesalahan pengambilan sampel variasi retiabilitas dan faktor lainnya yang tidak teridentifikasi adalah sebagai berikut: (a) varians yang disebabkan oleh variasi reliabilitas $=0,034$ $\%$, dan (c) faktorlain yang belum terpesifikasi adalah $96,2 \%$. Persentase varians yang disebabkan oleh sampling error adalah 3.751 \% dan karena factor lain yang belum terspesifikasi adalah $96.249 \%$. Jadi kesalahan yang disebabkan karena kesalahan sampling maupun kesalahan pengukuran pada aspek dukungan afeksi relative Kecil.

Hasil meta-analisis tentang hubungan variabel-variabel interaksi sosial positif terhadap PTSD adalah sebagai berikut : (1) Estimasi Mean korelasi populasi, $x y(r)=-0,371$; (2) varians korelasi populasi, $S^{2}\left({ }^{2}\right)=0,035$; (3) varians error, ${ }^{2} e=$ 0,003 ; (4) varians terkoreksi, $(x y)=0,032 ;(5)$ mean gabungan faktor penyusut artifaks, (A) $=30.920$ (6) estimasi mean korelasi populasi setelah dikorekasi measurement error $0=$ Ave $(A)=$ Ave $(\dot{r}): \quad=-0,012 ;(T)$ jumlah kuadrat koefisien varians $(V)=0,005$; (8) varians yang disebabkan oleh variasi artifak, $\mathbf{S}^{2}={ }^{2} \mathbf{A}^{2}=0,0007$; (9) varians korelasi yang sebenarnya $\operatorname{Var} 0=0,000033,(10) \mathrm{SD} 0=$ 0,006 . (11) batas korelasi populasi yang sudah dikoreksi karena kesalahan pengukuran pada interval kepercayaan $95 \%$ adalah: $-0,023 \quad-0,0008$. Analisis dampak kesalahan pengambilan sampel variasl reliabilitas dan faktor lainnya yang tidak teridentifikasi adalah sebagai berikut: (a) varians yang disebabkan oleh variasi reliabilitas $=2.026 \%$ dan (c) faktor lainnya adalah $89,7 \%$. Persentase varians yang disebabkan oleh sampling error adalah 8.952 $\%$ dan karena factor lain yang belum terspesifikasi adalah $91.783 \%$. Jadi kesalahan yang disebabkan karena kesalahan sampling pada aspek interaksi soslai positif relative besar dan kesalahan pengukuran relative kecil.

Hasil meta-analisis tentang hubungan variabel-variabel dukungan sarana \& aktivitas terhadap PTSD adalah sebagai berikut : (1) Estimasi Mean korelasi populasi, $x y(r)=0,004$; (2) varians korelasi, $S^{2}\left({ }^{2}\right)=0,034$; (3) vartans error, ${ }^{2} e=0,185$; (4) varians terkoreksi, $(x y)=0,072 ;(5)$ mean 
gabungan faktor penyusut artifaks, $(A)=$ 0,929 ; (6) korelasi yang terkoreksi $0=$ Ave (A) $=$ Ave $(r):=0,023 ;(7)$ jumlah kuadrat koefisien varians $(V)=0,000$; $(8)$ varians yang disebabkan oleh variasi artifak, $S^{2}={ }^{2} A^{2}$ $=0,0000 ;$ (9) varians korelasi yang sebenarnya $\operatorname{Var} 0=0,0265$, (10) $\mathrm{SD} 0=$ 0,163 (11) interval kepercayaan $95 \%$ adalah: $-0,2920,026$. Analisis dampak kesalahan pengambilan sampel variasi reliabilitas dan faktor lainnya yang tidak teridentifikasi adalah sebagai berikut: (a) varians yang disebabkan oleh variasi reliabilitas $=0,0 \%$ dan (c) faktor lainnya adalah $(66,7 \%)$. Jadi kesalahan yang disebabkan karena kesalahan pengukuran pada aspek dukungan afeksi relative kecil.

Selain lembar kerja mela analisis untuk aspek social support dengan PTSD juga akan dilakukan perhitungan korelasi aspek exposure dengan PTSD untuk memastikan adanya variabel moderator pada kedua variabel tersebut.

Tabel 8.

Hubungan antara exposure (trauma) dengan PTSD

\begin{tabular}{|c|c|c|c|c|c|c|c|c|c|c|c|c|}
\hline \multirow{2}{*}{$\begin{array}{l}\text { No. } \\
\text { Stud } \\
\text { I }\end{array}$} & \multirow[b]{2}{*}{ Peneliti } & \multirow[b]{2}{*}{ Tahun } & \multirow{2}{*}{$-\frac{\text { Sut }}{\text { yek }}$} & \multirow[t]{2}{*}{$\begin{array}{c}\text { Garakten } \\
\text { obk }\end{array}$} & \multirow[t]{2}{*}{$x$} & \multirow[t]{2}{*}{$\mathbf{Y}$} & \multirow[t]{2}{*}{5} & \multirow[t]{2}{*}{ p } & \multicolumn{2}{|c|}{ Peliab"iss } & \multicolumn{2}{|c|}{$\begin{array}{c}\text { Koreksi Kesthn } \\
\text { Pengkm }\end{array}$} \\
\hline & & & & & & & & & f. & r & $a=$ & $b=r$ \\
\hline (1) & (2) & (3) & (4) & (5) & (6) & (7) & (8) & $(9)$ & (10) & (11) & [12) & (13) \\
\hline 1. & $\begin{array}{l}\text { Strephons } \\
\text { S Long }\end{array}$ & 1949 & 517 & Pohsi & $\begin{array}{l}\text { Humatic } \\
\text { experience }\end{array}$ & PTSD & 028 & $\begin{array}{c}-000 \\
1\end{array}$ & - & 090 & - & 0.949 \\
\hline 2. & $\begin{array}{l}\text { Silophents } \\
\text { A Long }\end{array}$ & 2000 & 486 & Polsi & stessors & PTSD & 028 & 40.05 & - & 0.90 & - & 0.949 \\
\hline $\begin{array}{l}3 \\
\text { a) }\end{array}$ & $\begin{array}{l}\text { Tutiter } \\
\text { dak. }\end{array}$ & 2000 & 85 & Dewasa & $\begin{array}{l}\text { Hear the } \\
\text { bomb }\end{array}$ & PTSD & 024 & 0004 & & - & & - \\
\hline b) & $\begin{array}{l}\text { Tucker } \\
\text { dikk. }\end{array}$ & 2000 & 85 & Dewasa & $\begin{array}{l}\text { Foed } \\
\text { the boith }\end{array}$ & PTSD & 0.27 & 0.043 & & - & & - \\
\hline c & $\begin{array}{l}\text { Tucker } \\
\text { dik. }\end{array}$ & 2000 & 85 & Dewasa & $\begin{array}{l}\text { Dantage } \\
\text { Neraty } \\
\text { buindings }\end{array}$ & PTSD & -0.11 & 0.336 & & - & & - \\
\hline d) & $\begin{array}{l}\text { Tutier } \\
\text { dide }\end{array}$ & 2000 & 85 & Dewasa & $\begin{array}{l}\text { Told to } \\
\text { leswe } \\
\text { puitings }\end{array}$ & PTSD & 0.04 & 0725 & & - & & - \\
\hline ㅂ) & $\begin{array}{l}\text { Tucter } \\
\text { citk. }\end{array}$ & 2000 & 85 & Dewasa & Self-Injured & PTSD & 040 & $\begin{array}{c}0000 \\
3\end{array}$ & & - & & - \\
\hline 7) & $\begin{array}{l}\text { Tucker } \\
\text { ddk }\end{array}$ & 2000 & 85 & Dewasa & $\begin{array}{l}\text { Pecple } \\
\text { injured }\end{array}$ & PTSD & 0.29 & $\begin{array}{c}0.009 \\
5\end{array}$ & & $\cdot$ & & - \\
\hline$\phi$ & $\begin{array}{l}\text { Tucker } \\
\text { dikk. }\end{array}$ & 2000 & 85 & Dewasa & $\begin{array}{l}\text { Whatch } \\
\text { bemb- } \\
\text { nelatodTV }\end{array}$ & PTSD & 0.04 & 0.741 & & - & & - \\
\hline hì & $\begin{array}{l}\text { Tudker } \\
\text { duk }\end{array}$ & 2000 & 85 & Dewasa & $\begin{array}{l}\text { Go to the } \\
\text { site }\end{array}$ & PTSD & 0.30 & 0007 & & - & & + \\
\hline i) & $\begin{array}{l}\text { Tucker } \\
\text { cta }\end{array}$ & 2000 & 85 & Dewasa & $\begin{array}{l}\text { Attend } \\
\text { funeral }\end{array}$ & PTSD & 0.27 & 0.014 & & - & & - \\
\hline D & $\begin{array}{l}\text { Tucker } \\
\text { dikk. }\end{array}$ & 2000 & 85 & Dewrasa & $\begin{array}{l}\text { Close to the } \\
\text { buildings }\end{array}$ & PTSD & 0.18 & 0.108 & & - & & - \\
\hline k) & $\begin{array}{l}\text { Tuctur } \\
\text { dik }\end{array}$ & 2000 & 85 & Dewasa & $\begin{array}{l}\text { Co } \\
\text { lminediately } \\
\text { to the aits }\end{array}$ & PTSD & a3s & 0002 & & - & & - \\
\hline 1) & $\begin{array}{l}\text { Tucker } \\
\text { dkk. }\end{array}$ & 2000 & 65 & Dewasa & $\begin{array}{l}\text { bomb } \\
\text { Threats }\end{array}$ & PTSD & 0.20 & $D 0 B O$ & & $\cdot$ & & *. \\
\hline$m$ & $\begin{array}{l}\text { Tudut } \\
\text { didt }\end{array}$ & 2000 & 85 & Dewasa & $\begin{array}{l}\text { Family } \\
\text { injured }\end{array}$ & PTSD & 0.19 & 0.084 & & - & & - \\
\hline กุ่ & $\begin{array}{l}\text { Tuctior } \\
\text { dikk }\end{array}$ & 2000 & 85 & Dewasa & $\begin{array}{l}\text { Relative } \\
\text { injured }\end{array}$ & PTSD & 022 & 0.050 & & - & & . \\
\hline
\end{tabular}




\begin{tabular}{|c|c|c|c|c|c|c|c|c|c|c|c|c|}
\hline o) & $\begin{array}{l}\text { Tucteer } \\
\text { dkk. }\end{array}$ & 2000 & 85 & Dewasa & $\begin{array}{l}\text { Friend } \\
\text { injured }\end{array}$ & PTSD & 0.21 & 0,060 & & - & & - \\
\hline p) & $\begin{array}{l}\text { Tucker } \\
\text { dkk. }\end{array}$ & 2000 & 85 & Denuesa & $\begin{array}{l}\text { Someone } \\
\text { injured }\end{array}$ & PTSD & -001 & 0.933 & & - & & - \\
\hline a) & $\begin{array}{l}\text { Tucter } \\
\text { ddk. }\end{array}$ & 2000 & 85 & Demesa & $\begin{array}{l}\text { Family } \\
\text { killed }\end{array}$ & FTSD & 0.25 & 0.027 & & - & & - \\
\hline n) & $\begin{array}{l}\text { Tucter } \\
\text { ddk. }\end{array}$ & 2000 & 85 & Dentidet & $\begin{array}{l}\text { Friend } \\
\text { Kalled }\end{array}$ & FISD & 0.01 & 0.990 & & - & & 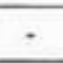 \\
\hline 4 & $\begin{array}{l}\text { Tucker } \\
\text { didk }\end{array}$ & 2000 & 85 & Dewcasa & $\begin{array}{l}\text { Someone } \\
\text { killed }\end{array}$ & FTSD & 0.21 & 0.658 & & - & & - \\
\hline 4 & $\begin{array}{l}\text { Sett } \\
\text { Brown }\end{array}$ & 2004 & 121 & $\begin{array}{l}\text { Remaja } \\
\text { Bvmangl } \\
\text { ua }\end{array}$ & $\begin{array}{l}\text { Communiky } \\
\text { violesrce } \\
\text { exposure }\end{array}$ & PTSD & 0.41 & 80.01 & & - & & - \\
\hline $\begin{array}{l}5 \\
\text { a }\end{array}$ & Aclemo & 2005 & $\begin{array}{c}113 \\
0\end{array}$ & Larised & $\begin{array}{l}\text { Prior } \\
\text { uratmatic } \\
\text { ewent- } \\
\text { exposure }\end{array}$ & PTSS & - & 40.6 & & & $=$ & \\
\hline b) & Aclamp & 2006 & 413 & dewasa & $\begin{array}{l}\text { Prior } \\
\text { traumatic } \\
\text { everrt } \\
\text { exposiure }\end{array}$ & PTSS & - & $\infty 0.05$ & & & & \\
\hline 6. & Hant & 2006 & 544 & Iensia & $\begin{array}{l}\text { Combat } \\
\text { exposure }\end{array}$ & PTSD & 0.29 & $=0.01$ & 0.91 & 0.97 & 0.954 & 0.985 \\
\hline
\end{tabular}

Hasil perhitungan pencarian variabel moderator terhadap sub kelompok yang berkorelasi dan sub kelompok yang tidak berkorelasi adalah: (1) sub kelompok yang berkorelasi sebanyak 21 studi; Hasilnya; = 0,235 (2) sub kelompok yang tidak berkorelasi sebanyak dua studi. Hasilnya; =0,06 ; Dari hasil perhitungan tersebut diketahui adanya perbedaan mean,perbedaan ini diperkirakan adanya variabel moderator dan dari kajian teoritik salah satunya adalah social support.

\section{PEMBAHASAN}

Mencermati hasil secara keseluruhan dari koreksi artefak yang dilakukan melalui studi primer diperoleh nilai signifikansi di mana aspek dukungan afeksi dan sarana \& aktifitas memiliki sumbangan terhadap PTSD Hal Ini dapat disimpulkan seluruh korelasi yang dikoreksi baik dari kesalahan pengambilan sampel dan pengukuran masih diambang batas interval kepercayaan $95 \%$. Namun demikian kesalahan pengambilan sampel yang cukup tinggi terjadi pada aspek dukungan social support total dan dukungan interaksi sosial yang positif yang mana kemungkinan disebabkan overlapping dalam pengukuran terhadap variabel-variabel tersebut karena penyatuan beberapa konsep yang berbeda dalam satu aspek dapat mengandung risiko.

Dart rangkajan penelitian terdapat buktl bahwa social support, khususnya dukungan afeksi dan dukungan sarana \& aktivitas dapat menjadi suatu alternatif pemecahan terhadap permasalahan mengatasi kesehatan mental masyarakat pasca bencana. Hal ini sesuai dengan pendapat Tucker et al (2000) bantuan afeksi dari konselor memprediksi masalah traumatik pasca bencana. Berbagai macam emosi negatif tidak lama setelah bencana (peritraumafic stress) yang tidak diatasi disinyalir akan menjadi prediktor kemunculan PTSD (Tichenor, dkk. 1996).

\section{PENUTUP}

Berdasarkan hasil analisis terhadap studi primer yang dilakukan di sini aspek dukungan afeksi dan dukungan sarana \& aktifitas memiliki sumbangan terhadap PTSD, kesalahan yang terjadi masih dalam batas-batas yang dapat diterima secara psikometrik. 


\section{DAFTAR PUSTAKA}

Aciemo, R: Ruggiero, K, Jil Kilpatrick, D.G.; Resnick, H.S. \& Galea, S. 2006. Risk and Protective Factors for Psychopathology Among Older Versus Younger Adults After the 2004 Florida Hurricanes: Journal of Geriatric Psychiatry, 14, 12, 10511059.

Declercq, F. \& Palmans, V. 2006. Two Subjective Factors as Moderators between Critical Incidents and The Occurrence of Post Traumatic Stress Disorders: "Adult Attachment" and "Perception of Social Support: The British Psychological Society, 79, 323337.

Ehlers, A; Mayou, RA; \& Bryant, B. 1998. Psychological Predictors of Chronic Postraumatic Stress Disorder After Motor Vehicle Accidents: Joumal of Abnormal Psychology. Vol. 407, No. 3, 508-519.

Keltner, N. \& Dowben, J. 2007. Psychobiological Substrates of Postiraumatic Stress Disorder-Part 1.: Perspectives in Psychiatric Care, 43, 2,97-

Jones, $E_{;}$Vermaas, R.H.;McCartney, $H_{\text {; }}$ Beech, C.: Palmer, I.; Hyams, K. \& Wessely, S. 2003. Flashbacks and Post-traumatic Stress Disorder. the Genesis of a 20-th-century Diagnosis. British joumal of Psychiatry, 182, 158163.

Hart, C. L 2006. Posttraumatic Stress Symptomatology in Aging Combat Veterans: The Direct and Buffering Effects of Stress and Sosial Support. Unpublished Dissertation. University of Pittsburg,www google.com.

Hunter, J.E. \& Smith, F.L. 1990. Method of Meta- Analysis: Correcting Emor and Bias in Research Findings. USA: Sage Publications Inc.
Kaniasty, K. \& Norris, F.H. 1993. A Test of The Social Support Deterioration Model in The Context of Natural Disaster: Joumal of Personality and Social Psychology, 64, 3, 395-408.

Khouzam, H.R.\& Kissmeyer, P. 1997. Antidepressant Treatment, Post Traumatic Stress Disorder, Survivor Guilt and Spiritual Awakening: Joumal of Traumatic Stress, 10,4,691-696.

Linley, A.P. \& Joseph, S. 2005. Positive and Negative Changes Following Occupational Death Exposure: Joumal of Traumatic Stress, 18, 6, 75t-758.

Lit, B.T; King LA\& King, D. W. 1997. Warriors as Peacekeepers: Features of the Somaia Eperience and PTSD: Joumal of Consulting and Clinical Psychology, 65,6, 1001-1010.

Litz, B.T; Schlenger, W.E. Weathers, F.W; Caddell, J.M.;Fairbank, J.A. \& LaVange, L.M. 1997. Predictors of Emotional Numbing in Post-traumatic Stress Disorder. Joumal of Traumatic Stress, 10, 4, 607-

McMillenn, J.C.; Smith, E.M.\& Fisher, R.H. 1997. Perceived Benefit and Mental Helath After Three Types of Disaster: Jounal of Consulting and Clinical Psychology, 65,5 733-739.

Sarmawi, J. 2007. Hubungan Antara EFC dan Dukungan Sosial Dengan Kecenderungan Post-traumatic Stress Disorder Pada Siswa-siswi SMU N 1 Pundong Pasca Gempa di Bantul Yogyakarta, Skripsi: Tidak diterbitkan. Fakultas Psikologi Universitas Ahmad Dahlan Yogyakarta.

Self-Brown, S.R. 2004. Effect of Family Violance and Parental Psychopathology on The Psychological Outcomes of Urban Adolescents Exposed to Commurity Violence. Unpublished Dissertation. Lousiana State University. www. google.com. 
Silove, D.8 Steel, z. 2006. Understanding Community Psychosocial Need Aft Disasters: Implications for Mental Health Services: Journal of Postgraduate Medicine, 52, 2, 121124.

Sugiyanto, 2006. Metode Kuantitatif Metaanalisis. Bahan kuliah program doktor. Tidakditerbitkan

Stephens, C. \& Long, N. 1999. Post Traumatic Stress Disorders in the New Zealand Police: The Moerating Role of Social Support Following Traumatic Stress. Anxiety, Stress \& Coping, 12, 247-264.

Stephens, C. \& Long. N. 2000. Communication with Police Supervisors and Peers as a Buffer of Work- related Traumatic Stress: Joumal of Organizational Behavior, 21,4,407-424.

Taylor, S., Koch, W.J., Kuch, K., Crockett, D.J. \& Passey, G. 1998. The Stucture of Posttraumatic Stress Symptoms: Joumal of Abnomal Psychology, 107, 1. 154-160.
Tichenor, $V_{\text {; }}$ Marmar,C.R.; Weiss, D.S; Metzler, T,J, \& Ronfeldt, H.M. 1996. The Relationship of Peritraumatic Dissociation and Post-traumatic Stress: Findings in Female Vietnam Theatre Veterans: Journal of Consulting and Clinical Psychology, 64,5, 1054-1059.

Tucker, P; Pfefferbaum, B; Nixon, S.J \& Dickson, W. 2000. Predictors of PostTraumatic Stress Symptoms in Oklahoma City: Exposure, Social support, Peri-Traumatic Responses: The Journal of Behavioral Health Services \& Research, 27, 4, 406-416.

Wilson, S.A.; Becker, L.A \& Tinker, R.H. 1997. Fifteen-Month Follow-Upof EyeMovement Desensitization and Reprocessing (EMDR) Treatment For Post-traumatic Stress Disorder and Psychological Trauma: Journal of Consulting and Clinical Psychology, $65,6,1047-1056$.

Winje, D. 1998. Cognitive Coping: The Psychological Significance of Knowing What happened in the Traumatic Event: Joumal of Traumatic Stress, $11,4,627-643$. 